\title{
Drip Irrigated Sunflower Intercropping
}

\author{
Abel Henrique Santos Gomes, Lucia Helena Garófalo Chaves*, \\ Hugo Orlando Carvallo Guerra \\ Federal University of Campina Grande, Campina Grande, Brazil \\ Email: "Ihgarofalo@hotmail.com
}

Received 4 July 2015; accepted 25 July 2015; published 28 July 2015

Copyright (C) 2015 by authors and Scientific Research Publishing Inc.

This work is licensed under the Creative Commons Attribution International License (CC BY). http://creativecommons.org/licenses/by/4.0/

(c) (i) Open Access

\begin{abstract}
One of the difficulties in the implementation of agroenergy's cropping is the growing area competition with subsistence crops. Few studies have been conducted to show the efficiency of intercropping between plants of energy's potential with cultures of economic sustainability. The objective of this study was to evaluate the effectiveness of intercropping sunflower cultivars with corn and beans, in the initial growth under localized irrigation. The experiment was conducted at the end of the year 2012, in an area of $950 \mathrm{~m}^{2}$, located in the Campus II-UEPB, Lagoa Seca, Paraíba. The irrigation system was managed based on the Reference Evapotranspiration (ETo), calculated by the Penmann-Monteith Method with data obtained locally. The experimental design was a randomized blocks factorial $(2 \times 4) \times 3$, with treatments combining two varieties of sunflower in four plantation systems: single or isolated, intercropped with maize, with bean and with caupi. Each plot consisted of four rows of sunflowers in spacing $0.3 \times 0.7 \mathrm{~m}$ and length of $5 \mathrm{~m}$, interspersed with rows of beans or corn, except in the isolated system. The central rows of sunflowers were used to measure the following growth characteristics: plant height, stem diameter, number of leaves and leaf área. Data were subjected to analysis of variance by $F$ test and the means compared by Tukey test at $5 \%$ probability. The diversification of sunflower varieties promoted differences in initial growth, regardless of the cropping system. There was significant effect at 15 DAS, where the sunflower variety "Advanta CF101" had higher plants than the variety "Hélio 253" at 40 DAS; the variety "Hélio 253" had a stem diameter greater than the "Advanta CF101".
\end{abstract}

\section{Keywords}

Helliantus Annus, Maize Hybrid 2B587, Bean Carioca BRS, Cowpea IPA206, Plant Growth

\section{Introduction}

Intercropping, an old agricultural practice, consists of a simultaneous growth of two or more species in the same "Corresponding author. 
area where they share resources (soil, water, nutrients) during all or part of their growing season [1]. This culture system commonly occurs competition for nutrients, water and soil; the level of this competition varies according to local conditions and the species involved which is directly reflected in productivity achieved. However, operational cultivation such as manpower, time of cultivation, irrigation and others are minimized and optimized by the intercropping [2]. Another important advantage is the biological control that occurs when the consortiation diversifies the species grown in the same area [3].

Intercropping of oil crops, preferably for biodiesel production purposes, with subsistence crops has been encouraged since 2002 by the National Biofuels Program, however, planting these species must not compete with the food market occurring the minimum competition for natural resources [4].

The arrangement of sunflower-corn-beans intercropping is an option for social inclusion of small farmers and can provide an additional source of income in generating opportunities for the population, mainly in the northeastern agricultural regions [5]. The scarce result of this intercropping system has shown yields near and even higher than monoculture systems [6] [7].

Because the importance of subsistence crops and the potential of sunflower to produce biodiesel and the few studies in northeastern Brazil on intercropping cultures, it is extremely important to conduct research to furnish information to small farmers. In this sense, the aim of the present study was to evaluate the growth and production of sunflower genotypes Advanta CF 101 and Helio 253, growing in the field, in isolated and intercropped system with corn and bean and measure the land equivalent ratio index of sunflower intercropped to maize and beans, to assess the effects of the intercropping system, and to gain insight into ecophysiological processes affecting their yield determination.

\section{Materials and Methods}

The experiment was carried out from September to November 2012 under field conditions at an Entisol soil located at Center for Agricultural and Environmental Sciences of the State University of Paraíba, Paraiba State, Brazil. This soil had the chemical attributes determined by using the procedures recommended by [8]: $\mathrm{pH}(1: 2.5$; soil: $\mathrm{H}_{2} \mathrm{O}$ ratio) $=5.85 ; \mathrm{Ca}^{2+}=6.28 \mathrm{cmol}_{\mathrm{C}} / \mathrm{kg}^{-1} ; \mathrm{Mg}^{2+}=6.37 \mathrm{cmol}_{\mathrm{C}} / \mathrm{kg}^{-1} ; \mathrm{Na}=0.18 \mathrm{cmol}_{\mathrm{C}} / \mathrm{kg}^{-1} ; \mathrm{K}^{+}=0.88$ $\mathrm{cmol}_{\mathrm{C}} / \mathrm{kg}^{-1} ; \mathrm{H}^{+}+\mathrm{Al}^{3+}=5.28 \mathrm{cmol}_{\mathrm{C}} / \mathrm{kg}^{-1}$; organic matter $=27.7 \mathrm{~g} / \mathrm{kg}^{-1}$; Available $\mathrm{P}=54.0 \mathrm{mg} / \mathrm{kg}^{-1}$.

A week before planting, the soil was plowed, harrowed and fertilized with $60: 80: 100 \mathrm{~kg} / \mathrm{ha}$ of $\mathrm{N}: \mathrm{P}_{2} \mathrm{O}_{5}: \mathrm{K}_{2} \mathrm{O}$ using as sources of nutrients urea, superphosphate, potassium chloride and $2.0 \mathrm{~kg}$ boron/ha as boric acid. Nitrogen fertilization was splitted: $1 / 3 \mathrm{~N}$ applied to foundation and the remaining 2/3 in coverage 45 days after sowing; other nutrients were also fully applied at sowing. Sowing was performed just after the beginning of the rainy season in the $0.7 \mathrm{~m}$ separated rows, placing manually at $0.3 \mathrm{~m} 03$ seeds for each hole (pit), at $3 \mathrm{~cm}$ depth.

The thinning occurred on the seventh day after emergency eliminating manually plants that visually were weak or less developed. The irrigation management was based on the daily reference evapotranspiration estimated by the Penmann Monteith method using meteorological data obtained from a automatic weather station located in the area. For the irrigation of the area it was used a drip system constituted by a $3 \mathrm{CV}$ water bomb, a tertiary line of PVC of $60 \mathrm{~mm}$ diameter and three secondary lines of PVC $25 \mathrm{~mm}$ of diameter. Each secondary line supplied 8 dripping lines of $16 \mathrm{~mm}$ diameter with emitters flow rates of $1.02 \mathrm{l} / \mathrm{h}^{-1}$ at a pressure service of 55 meters of water head.

Weeds were controlled by hoeing's at the 20 and 40 days after sowing.

The harvest was conducted manually when the sunflower heads had a dark brown coloration, stage when the achenes have water content around $14 \%$ and $16 \%$ [9]. After harvest the heads were bagged, identified and placed in a dry environment to reach a $11 \%$ water content. Finally, the achenes were collected and the sunflower post-harvest variables evaluated.

The experimental design was a randomized block factorial with eight treatments and three replicates. The treatments consisted of two varieties of sunflower (Advanta CF 101-V1 and Hélio 253-V2) cultivated isolated and intercropped with maize Hybrid 2B587, bean Carioca BRS Requinte and Cowpea IPA206. Each plot consisted of four sunflower rows that, in the case of intercropping plots were intercalated with three rows of beans or corn. Each experimental row had length of $5.0 \mathrm{~m}$ a row spacing of $0.7 \mathrm{~m} 0.3 \mathrm{~m}$ among plants.

At 90 DAS, plant height, insertion head height, diameter of the head and number of leaves were evaluated in five plants. Due to the premature falling of the leaves the leaf area was determined at 65 DAS. After harvested, the heads were air dried to reach moisture content of $13 \%$. Thereafter it was determined manually the weight and number of the achenes. Similarly the corn and bean grain production were quantified. 
With these data the Land Efficiency Rate (LER) index [10] (Andrew and Kassam, 1976), was obtained according to the expression: ULE = IA/MA + IB/MB where IA = yield of the crop A intercropped; MA = yield of the crop A isolated; $\mathrm{IB}=$ yield of the crop $\mathrm{B}$ intercropped and $\mathrm{MB}=$ yield of the crop $\mathrm{B}$ isolated.

The variables data measured in each treatment were transcribed to computer spreadsheets and analyzed statistically through the analyses of variance (ANOVA). When the qualitative factor was significant, the results were submitted to the Tukey Test. Data for ULE are only descriptive and were not analyzed statistically [11].

\section{Results and Discussion}

The height of sunflower plants was influenced significantly by the varieties to $1 \%$ probability, however, it was not affected by the cultivation treatments. The Advanta CF 101 variety reached, on average a height of $1.12 \mathrm{~m}$. smaller than Helio 253 variety which reached 1.18 m (Table 1).

The effect of the variety treatment over the chapter insertion height was also significant at the $1 \%$ level of probability. The variety Advanta CF 101 had a chapter insertion height of $0.95 \mathrm{~m}$, smaller than the one observed on the variety Helio $253(1.09 \mathrm{~m})$. The chapter insertion height for the variety was not influenced by the crop systems (see Tukey test in Table 1), however comparing the crop systems for the variey Advanta CF 101 and the Helio 253 separately, there was some differences (Figure 1). Thus, the Advanta sunflower variety intercropped with corn (V1S2) had a smaller chapter insertion height $(0.91 \mathrm{~m})$ than the Helio 253 intercropped with corn (V2S2) (1.07 m). Similarly, the Advanta sunflower variety intercropped with Caupi (V1S4) had a smaller chapter insertion height $(0.91 \mathrm{~m})$ than the Helio 253 intercropped with Caupi (V2S4) (1.06 m).

The number of leaves was not influenced by the varieties, however, it was affected by the cultivation treatments (Table 1). Sunflower plants cultivated isolated had a media of 22 leaves per plant, statistically equal to

Table 1. Analysis of variance for plant height (PH), chapter insertion height (CIH), leaf number (LN), leaf area (LA) and grais yields (Y) for the diferent sunflower varieties and crop systems.

\begin{tabular}{|c|c|c|c|c|c|c|}
\hline \multirow[t]{2}{*}{ Fonte de variação } & \multirow[t]{2}{*}{ GL } & \multicolumn{4}{|c|}{ Mean Squares } & \multirow[b]{2}{*}{$\mathrm{Y}$} \\
\hline & & $\mathrm{PH}$ & $\mathrm{CIH}$ & $\mathrm{LN}$ & LA & \\
\hline Variety (V) & 1 & $192.67^{* *}$ & $1012.96^{* *}$ & 0.37 & 6072065.10 & $1650399^{* * *}$ \\
\hline Crop System (CS) & 3 & 47.35 & 94.86 & $5.71^{* *}$ & 2603097.81 & $924203^{*}$ \\
\hline$(\mathrm{V}) \times(\mathrm{CS})$ & 3 & 67.16 & 14.47 & 0.26 & 1220643.26 & 190494 \\
\hline Treatments & 7 & $76.59^{*}$ & $191.56^{*}$ & 2.61 & 2506184.05 & $713498^{*}$ \\
\hline Blocks & 2 & 108. $06^{*}$ & 49.31 & $30.50^{* *}$ & $7076396.56^{*}$ & 282872 \\
\hline Resídue & 14 & 21.74 & 51.9 & 1.02 & 1614047.45 & 170185 \\
\hline \multirow[t]{2}{*}{ CV (\%) } & & 4.06 & 7.02 & 4.91 & 17.62 & 20.92 \\
\hline & & $\mathrm{PH}(\mathrm{m})$ & $\mathrm{CIH}(\mathrm{m})$ & $\mathrm{LN}$ & $\mathrm{LA}\left(\mathrm{cm}^{2}\right)$ & $\mathrm{Y}\left(\mathrm{kg} / \mathrm{ha}^{-1}\right)$ \\
\hline \multicolumn{7}{|l|}{ Variety } \\
\hline Advanta CF 101 & & $1.12 \mathrm{~b}$ & $0.95 \mathrm{~b}$ & $21 \mathrm{a}$ & 2986.05 a & 2234.65 a \\
\hline Hélio 253 & & $1.18 \mathrm{a}$ & $1.09 \mathrm{a}$ & $20 \mathrm{a}$ & 3992.03 a & $1710.19 \mathrm{~b}$ \\
\hline \multicolumn{7}{|l|}{ System } \\
\hline Isolated sunflower & & $1.17 \mathrm{a}$ & $1.05 \mathrm{a}$ & $22 \mathrm{a}$ & 3327.42 a & 2213.73 a \\
\hline Sunflower + corn & & $1.11 \mathrm{a}$ & 0.99 a & $19 \mathrm{~b}$ & 2641.73 a & $1389.09 \mathrm{~b}$ \\
\hline Sunflower + Carioca bean & & $1.15 \mathrm{a}$ & $1.06 \mathrm{a}$ & $21 \mathrm{a}$ & 4149.29 a & $2194.00 \mathrm{a}$ \\
\hline Sunflower + Caupi bean & & $1.15 \mathrm{a}$ & $0.98 \mathrm{a}$ & 20 a & 3837.71 a & 2092.86 a \\
\hline Mean & & 1.15 & 1.02 & 21 & 3489.04 & 1972.42 \\
\hline
\end{tabular}

*** significant to $5 \%$ and $1 \%$ probability by the $\mathrm{F}$ Test $\mathrm{F}$, respectively. Means followed by different letter differ statically by the Tukey test at $5 \%$ probability. 


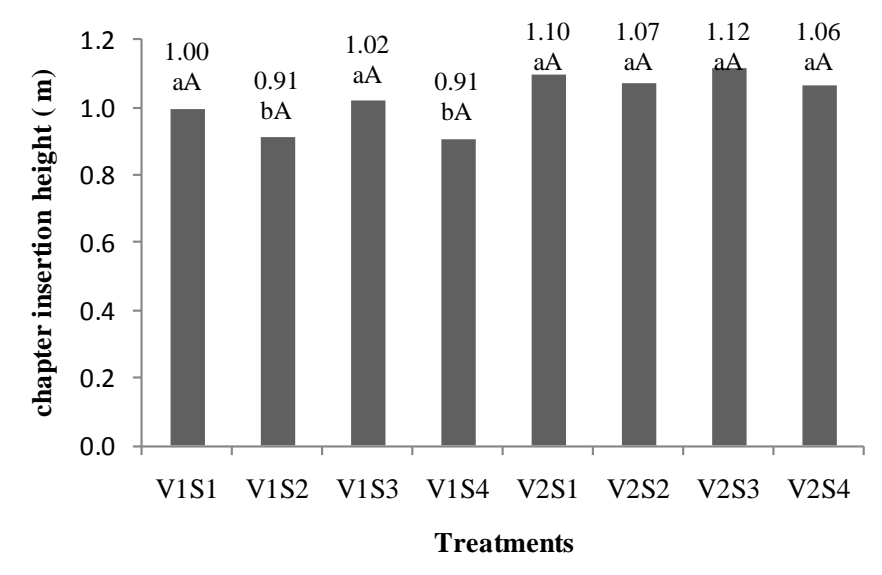

Figure 1. Chapter insertion Heights for the treaments of sunflower variety ans crop systems. Means followed by different small letters (variety) and capital letters (crop system) differ statistically by the Tukey test at $5 \%$ probability.

the girassol consociated with the beans, but higher to the girassol consociated with corn. All these values are normal according with [12], however lower than the values found by [13] of 28 leaves by plant.

The plant leaf area (LA) was not influenced by sunflower varieties and cultivation systems, however the variety Advanta CF 101 showed a mean leaf area in $2986.05 \mathrm{~cm}^{2}$ while Helium 253 showed $3992.03 \mathrm{~cm}^{2}$ (Table 1).

Sunflower grain yields was influenced by varieties to the level of $1 \%$ probability, and the cropping systems at 5\% probability, corroborating [14] who worked in the state of Sergipe with different cropping systems.

Advanta CF 101 variety had a grain yield average of $2234 \mathrm{~kg} / \mathrm{ha}^{-1}$, statistical superiority to Helium 253 variety with an average of $1710 \mathrm{~kg} / \mathrm{ha}^{-1}$ (Table 1) however lower than the yields found by [9] and [14] who obtained an average of $2310 \mathrm{~kg} / \mathrm{ha}^{-1}$. The average yield of the Advanta CF 101 variety was also higher than that found by [15] when evaluating the same variety in the state of Maranhão, but lower than in an experiment carried out in Rio Grande do Sul, by the same authors, with an average yield of $3079 \mathrm{~kg} / \mathrm{ha}^{-1}$.

Cropping systems were statistically significant to the $0.05 \%$ probability. The yields of isolated sunflower, and the sunflower consociated with both beans cultivars were statistically greater than the sunflower consociated with corn, this last one producing the lowest grain yield, with an average of $1389.10 \mathrm{~kg} / \mathrm{ha}^{-1}$ which represented a reduction of $37.25 \%$ in comparison with the isolated system (Table 1). This was probably due to the fact of sunflower plants growing wit the corn had fewer leaves than in the other systems, thus receiving less solar radiation and consequently lower production of sunflower seeds.

The sunflower monoculture system did not differ statistically from the beans intercropping systems although the isolated sunflower obtained the highest yield of $2213 \mathrm{~kg} / \mathrm{ha}^{-1}$. The reduction percentage of intercropping with beans and cowpea relative to monoculture system were, respectively, $0.89 \%$ and $5.46 \%$; then the bean crop was the least interfered with sunflower productivity.

The overall average grain yield for sunflower cultivation in the experiment was $1972 \mathrm{~kg} / \mathrm{ha}^{-1}$, higher than the national average of $1250 \mathrm{~kg} / \mathrm{ha}^{-1}$ [16]. This yield was also higher than the $1450 \mathrm{~kg} / \mathrm{ha}^{-1}$ and $1843 \mathrm{~kg} / \mathrm{ha}^{-1}$ found by [17] and [18].

Table 2 presents the Land Efficient Rate (LER) for all the intercropped systems evaluated.

It is observed that all the LER obtained were higher than one, showing the advantage of intercropping over sunflower sole stands, in regard to the use of environmental resources for plant growth and thus crop production [19]. The results corroborates [20] and [21] which, evaluating the bean intercropping with castor bean and cowpea with maize cultivars, respectively, observed that these systems were more efficient than the monoculture systems.

It seems profitable on unit area basis to have the two crop combined in the same rows for most economical yields and the best usage of available land. These results provide documentary evidence of the superiority of intercropping over sole cropping by having maximum LER from 1.50 to 1.68 [22].

LER values for the system sunflower-corn were lower than intercropping with beans; probably as [23] state, due to the greater skill of bean plants in the use of production factors such as water, light and nutrients. 
Table 2. Land Efficient Rate (LER) for all the evaluated intercropping systems.

\begin{tabular}{cc}
\hline Intercropping Systems & LER \\
\hline Sunflower Advanta CF101 + maize & 1.3 \\
Sunflower Advanta CF101 + cowpea Bean & 1.8 \\
Sunflower Advanta CF101 + common bean (Phaseolus vulgaris) & 1.7 \\
Sunflower Hélio 253 + maize & 1.4 \\
Sunflower Hélio 253 + cowpea Bean & 1.9 \\
Sunflower Hélio 253 + common bean (Phaseolus vulgaris) & 1.7 \\
\hline
\end{tabular}

\section{Conclusions}

Diversification of sunflower varieties promoted differences in growth and production patterns, regardless if consociated or isolated. The Advanta CF101 had the higher production.

The cultivation system affected only the number of leaves and grain production.

The LER obtained with the intercropping systems were higher than the one obtained with the isoloated systems, showing thus that the intercropping systems are more efficient than the monoculture.

The LER values for the Intercropping sunflower-beans were higher than the one obtained for the sunflowercorn, probably due to the greater skill of bean plants to use the production factors such as water, light and nutrients.

\section{References}

[1] Sudo, A., Guerra, J.G.M., Almeida, D.L. and Ribeiro, R.L.D. (1998) Cultivo consorciado de cenoura e alface sob manejo orgânico. CNPAB, Seropédica.

[2] Araújo Júnior, B.B. (2010) Crescimento e rendimento de milho cultivado com controle de plantas daninhas via consorciação com gliricídia. MSc. Dissertation, Universidade Federal Rural do Semiárido, Mossoró.

[3] Teixeira, I.R., Mota, J.H. and Silva, A.G. (2005) Consórcio de hortaliças. Semina: Ciências Agrárias, 26, 507-514. http://dx.doi.org/10.5433/1679-0359.2005v26n4p507

[4] Smeets, E.M.W. and Faaij, A.P.C. (2010) The Impact of Sustainability Criteria on the Costs and Potencials of Bioenergy Production-Applied for Case Studies in Brazil and Ukraine. Biomass and Bioenergy, 34, 319-333. http://www.sciencedirect.com/science/article/pii/S0961953409002323 http://dx.doi.org/10.1016/j.biombioe.2009.11.003

[5] Câmara, G.M.S. (2001) O Agronegócio das plantas oleaginosas: Algodão, amendoim, girassol e mamona. ESALQ, Piracicaba.

[6] Rodrigues, C.F., Bezzera, A.R., Pitombeira, J.B., Carvalho, C.M., Silva, L.L. and Feitosa, S.O. (2014) Sistema de consórcio do girassol, feijão de corda e amendoim em séries de substituição. Revista Brasileira de Agricultura Irrigada, 8, 256-269. http://dx.doi.org/10.7127/rbai.v8n300207

[7] De Souza, F.R., Da Silva, I.M., Pellin, D.M.P., Bergamin, A.C. and Da Silva, R.P. (2015) Características agronômicas do cultivo do girassol consorciado com Brachiaria ruziziensis. Revista Ciência Agronômica, 46, 110-116.

[8] EMBRAPA, Centro Nacional de Pesquisa de Solos (1997) Manual de métodos de analise de solo. 2nd Edition, Embrapa, Rio de Janeiro.

[9] Lira, M.A., Chagas Carvalho, H.W.L., Carvalho, C.G.P., Lima, J.M.P. and Medeiros, A.A. (2011) Desempenho de cultivares de girassol no estado do Rio Grande do Norte. EMPARN, Natal.

[10] Andrews, D.J. and Kassam, A.H. (1976) The Importance of Multiple Cropping in Increasing World Food Supplies in Multiple Cropping. American Society of Agronomy, 27, 1-10. https://www.agronomy.org

[11] Ferreira, D.F. (2000) Sistema de análises de variância para dados balanceados. UFLA, Lavras. (SISVAR 4. 1. Pacote computacional) http://www.scielo.br/scielo.php?script=sci_nlinks\&ref=000117\&pid=S0100-2945200900030002000012\&lng=en

[12] Castiglioni, V.B.R., Balla, A., Castro, C. and Silveira, J.M. (1997) Fases de desenvolvimento da planta de girassol. EMBRAPA-CNPSo, Londrina.

[13] Vogt, G.A., Balbino Junior, A.A. and De Souza, A.M. (2010) Divergência genética entre cultivares de girassol no planalto norte catarinense. Scientia Agraria, 11, 307-315. 
[14] Rodrigues, C.S., Oliveira, I.R., Carvalho, H.W.L., Carvalho, L.M., Castro, C.R., Menezes, V.M.M. and Carvalho, C.G.P. (2011) Consórcio do girassol com milho e feijão no agreste sergipano. Proceedings Reunião Nacional de Pesquisa de Girassol/7 Simpósio Nacional Sobre a Cultura do Girassol, Aracaju, CD-ROM.

[15] Carvalho, C.G.P., Grunvald, A.K., Oliveira, A.C.B., Salasar, F.P.L.T., Silva, F.P., Campos, R. and Fagundes, R.A. (2011) Informes da avaliação de genótipos de girassol 2010/2011 e 2011. Embrapa Soja, Londrina.

[16] CONAB —Companhia Nacional de Abastecimento (2011) http://www.conab.gov.br.

[17] Menezes, V.M.M., Oliveira, I.R., Carvalho, H.W.L., Rodrigues, C.S., Carvalho, L.M., Castro, C.R. and Carvalho, C.G.P. (2011) Potencial produtivo do girassol consorciado com feijão no semiárido baiano. Proceedings Reunião Nacional de Pesquisa de Girassol/7 $7^{\circ}$ Simpósio Nacional Sobre a Cultura do Girassol, Aracaju, CD-ROM.

[18] Oliveira, I.R., Carvalho, H.W.L., Castro, C.R., Rodrigues, C.S., Menezes, V.M.M., Carvalho, L.M. and Carvalho, C.G.P. (2011) Rendimento de aquênios de girassol quando em consórcio com feijão no alto sertão do sergipe. Proceedings Reunião Nacional de Pesquisa de Girassol/7 Simpósio Nacional Sobre a Cultura do Girassol, Aracaju, CD-ROM.

[19] Mead, R. and Willey, R.W. (1980) The Concept of a "Land Equivalent Ratio" and Advantages in Yields for Intercropping. Experimental Agriculture, 16, 217-228. http://dx.doi.org/10.1017/S0014479700010978 http://journals.cambridge.org/download.php?file=\%2FEAG\%2FEAG16 03\%2FS0014479700010978a.pdf\&code=1c2f 0c30d1688e92a22b52fd9ff5084a

[20] Teixeira, I.R., Silva, G.C., Timossi, P.C. and Silva, A.G. (2011) Desempenho agronômico de cultivares de feijão-comum consorciado com mamona. Revista Caatinga, 24, 55-61.

[21] Fernandes, S.S.L., Carneiro, L.F., Motta, I.S. and Padovan, M.P. (2012) Consorciação de feijão-caupi e milho em um agroecossistema manejado sob bases ecológicas na Região de Dourados, Mato Grosso do Sul. Proceedings Seminário de Agroecologia e 3 Encontro de Produtores Agroecológicos de Mato Grosso do Sul, Glória de Dourados, CD-ROM.

[22] Zada, L., Ahmad, S. and Nazar, M.S. (1988) Land Equivalent Ratios, Relative Yields and Relative Yield Total of Intercropped Maize and Soybean. Pakistan Journal of Agricultural Research, 9, 122-143. http://www.cabi.org/gara/FullTextPDF/Pre2000/19900731947.pdf

[23] Rosales, E.J.M. and Mora, O.F. (2009) Biomass, Yield and Land Equivalent Ratio of Helianthus annus L. in Sole Crop and Intercropped with Phaseolus vulgaris L. in High Valleys of Mexico. Tropical and Subtropical Agroecosystems, 10, 431-439. 